\title{
The Dynamic Behaviour of Capacitive Humidity Sensors
}

\author{
J. Majewski \\ Lublin University of Technology, \\ Nadbystrzycka str., 38A, Lublin 20-618, Poland
}

Received 04.10.2019

Accepted for publication 16.12.2019

\begin{abstract}
The sensor design features and the sensing material properties which can influence the response time of the polymer-based capacitive humidity sensors are shortly discussed. The ways of specifying the dynamic properties of capacitive humidity sensors in technical data sheets by the leading companies on the market are briefly characterized and discussed.

The schematic view and operation of the experimental setup for determining of the dynamic parameters of capacitive humidity sensors at different temperatures of humid air are described. The dynamic behaviour of polymer-based capacitive humidity sensors was registered as the measurement profiles for both positive and negative step changes in humidity level. The response and recovery times, as well as the time constants for the exponential approximation fits of the step responses, were determined either graphically or analytically, based on the collected data.

The changes of these parameters under atmospheric pressure within the temperature range from $-30{ }^{\circ} \mathrm{C}$ to $+20^{\circ} \mathrm{C}$ were analysed. The exemplary transient measurement profiles are shown, together with the illustrations of the graphical method for determining the response and recovery times. Also, the plots of the relationship between response and recovery times as well as time constants, and temperature, are presented. Some explanations of the obtained results are suggested.
\end{abstract}

Keywords: dynamic behaviour of sensors, response time temperature dependency, polymer-based capacitive humidity sensors, exponential approximations of sensor step response.

DOI: $10.21122 / 2220-9506-2020-11-1-53-59$

\begin{tabular}{ll}
\hline Aдрес для переписки: & Address for correspondence: \\
J. Majewski & J. Majewski \\
Lublin University of Technology, & Lublin University of Technology, \\
Nadbystrzycka str., 38A, Lublin 20-618, Poland & Nadbystrzycka str., 38A, Lublin 20-618, Poland \\
e-mail: j.majewski@pollub.pl & e-mail: j.majewski@pollub.pl \\
\hline Для цитирования: & For citation: \\
J. Majewski. & J. Majewski. \\
The Dупатіс Behaviour of Capacitive Humidity Sensors. & The Dynamic Behaviour of Capacitive Humidity Sensors. \\
Приборы и методы измерений. & Devices and Methods of Measurements. \\
2020. - Т. 11, № 1.- С. 53-59. & 2020, vol. 11, no. 1, pp. 53-59. \\
DОІ: $10.21122 / 2220-9506-2020-11-1-53-59$ & DOI: 10.21122/2220-9506-2020-11-1-53-59 \\
\hline
\end{tabular}




\section{Динамические характеристики ёмкостных датчиков}

\section{вЛажности}

\section{Я. Маевски}

Люблинский технический университет, ул. Надбыстрищкая, 38А, Люблин 20-618, Польша

Поступила 04.10.2019

Принята к печати 16.12.2019

Рассмотрены конструктивные параметры и свойства чувствительных материалов, влияющие на время отклика ёмкостных датчиков влажности на основе полимеров. Выполнен краткий обзор и анализ способов определения динамических характеристик ёмкостных датчиков влажности в технической документации ведущих производителей, представленных на рынке.

Приведено описание схемы и работы экспериментальной установки для определения динамических характеристик ёмкостных датчиков влажности при различных значениях температуры влажного воздуха. Динамические характеристики ёмкостных датчиков влажности на основе полимеров определялись в виде отклика выходного сигнала при ступенчатом изменении влажности как с положительным, так и с отрицательным шагом. Времена отклика и восстановления, а также постоянные времени для экспоненциальной аппроксимации отклика на ступенчатое воздействие, определялись на основе результатов измерений графически либо аналитически.

Проанализированы изменения указанных параметров в пределах температур от $-30{ }^{\circ} \mathrm{C}$ до $+20{ }^{\circ} \mathrm{C}$ при атмосферном давлении. Приведены примеры полученных переходных характеристик, проиллюстрирован графический метод определения времён отклика и восстановления. Представлены графики зависимости времён отклика и восстановления, а также постоянных времени, от температуры. Предложены возможные объяснения полученных результатов.

Ключевые слова: динамические характеристики датчиков, температурная зависимость времени отклика, ёмкостные датчики влажности на основе полимеров, экспоненциальная аппроксимация ступенчатого отклика датчика.

DOI: $10.21122 / 2220-9506-2020-11-1-53-59$

\begin{tabular}{ll}
\hline Aдрес для переписки: & Address for correspondence: \\
J. Majewski & J. Majewski \\
Lublin University of Technology, & Lublin University of Technology, \\
Nadbystrzycka str., 38A, Lublin 20-618, Poland & Nadbystrzycka str., 38A, Lublin 20-618, Poland \\
e-mail: j.majewski@pollub.pl & e-mail: j.majewski@pollub.pl \\
\hline Для цитирования: & For citation: \\
J. Majewski. & J. Majewski. \\
The Dупатіс Behaviour of Capacitive Humidity Sensors. & The Dynamic Behaviour of Capacitive Humidity Sensors. \\
Приборы и методы измерений. & Devices and Methods of Measurements. \\
2020. - Т. 11, № 1.- С. 53-59. & 2020, vol. 11, no. 1, pp. 53-59. \\
DОI: $10.21122 / 2220-9506-2020-11-1-53-59$ & DOI: 10.21122/2220-9506-2020-11-1-53-59 \\
\hline
\end{tabular}




\section{Introduction}

Humidity is one of the most commonly measured process variables in industry; also, a plenty of applications of humidity sensors both indoors and outdoors, from meteorology to medicine, can be mentioned. Generally, all the applications can be categorized into gas humidity measurements, and the moisture measurements in solid materials. For measuring of the gases humidity, the capacitive sensors are the popular choice because of many advantages, primarily: linearity, low power consumption, and broad operating temperature range [1].

As a rule, the sensing element of these sensors is a thin planar polymeric film placed between two parallel plate (PP) electrodes, or coated onto a pair of comb-like interdigitated electrodes (IDE) printed on a thick glasslike substrate. The arrangement of the electrodes has an influence on the dynamic properties of the sensor. The IDE-type arrangement allows faster response to a change in humidity than the PP-type because it takes longer to let an additional parcel of water molecules get inside or outside the sensing material layer, passing across the surface of the upper electrode. The time of response to a change in measured humidity depends also on the adsorption (or desorption) rate of the water molecules on the surface of the sensing polymeric film and is influenced by the diffusion rate into (or out of) the film $[2,3]$. The dead volume inside the housing of the sensor, the filter membrane protecting the sensing element from contaminations (if necessary) and the lack of airflow over the sensor can increase the response and recovery times considerably.

In the polymer-based capacitive humidity sensors which are designed for measuring relative humidity values, the thin humidity-sensitive layers are mostly made of polyimide (the detailed composition of the layer is usually the trade secret) $[2,4]$. Below the lower measurement range limit of $1-5 \% \mathrm{RH}$, for accurate measurement other sensing principles than capacitive, and other sensor designs are used; one of them is the coulometric-type sensor [5].

The manufacturers of humidity sensors provide in the specifications mainly the parameters concerning the steady properties: accuracy, measurement range, sensitivity, and sometimes the calibration equation and the temperature correction of the indication. The dynamic properties are usually omitted, or the time constant (commonly denoted as $t_{63}$ ) value is reported - because the dynamics of the step response of the humidity sensors is roughly described by a first order differential equation [4]. The temperature at which the $t_{63}$ value was obtained is rarely given (and then, as a rule, the room temperature between $+20{ }^{\circ} \mathrm{C}$ and $+25^{\circ} \mathrm{C}$ is stated [cf. Table 1]). Even more rarely, the magnitude of the humidity step and the airflow velocity are characterized. Moreover, the supplementary explanations on the methodology of the determination of the $t_{63}$ value are provided only sporadically (e.g. $[6,7])$.

Table

Examples of specifying the dynamic behaviour parameters of capacitive humidity sensors in technical data sheets from various market-leading manufacturers

\begin{tabular}{|c|c|c|c|}
\hline Company & Sensor & $\begin{array}{l}\text { Sensor's dynamic behaviour } \\
\text { described as: }\end{array}$ & Manufacturer's remarks or footnotes: \\
\hline IST & K5-W & Response time $t_{63}<5 \mathrm{~s}$ & $50 \% \mathrm{RH}$ to $0 \% \mathrm{RH}$ at $+23{ }^{\circ} \mathrm{C}[8]$ \\
\hline Honeywell & $\begin{array}{l}\text { HIH-4602-L } \\
\text { Series }\end{array}$ & Response time typical $30 \mathrm{~s}$ & $1 / \mathrm{e}$ in slow moving air [9] \\
\hline $\mathrm{E}+\mathrm{E}$ & HCT 01 & Response time $t_{63} \leq 6 \mathrm{~s}$ & @ $t_{\text {ref }}=30{ }^{\circ} \mathrm{C}(10 \% \mathrm{RH}$ to $90 \% \mathrm{RH})[10]$ \\
\hline Rotronic & $\begin{array}{l}\text { HygroMer } \mathbb{} \\
\text { IN-1 }\end{array}$ & $\begin{array}{l}\text { Humidity response time } t_{63} \\
<15 \mathrm{~s} \text { without filter }\end{array}$ & at $23^{\circ} \mathrm{C}$ and $1 \mathrm{~m} / \mathrm{s}$ [11] \\
\hline Sensirion & SHT 71, SHT 75 & $\begin{array}{l}\text { Response time } t_{63} \% \\
\text { typically } 8 \mathrm{~s}\end{array}$ & $\begin{array}{l}\text { Time for reaching } 63 \% \text { of a step function, valid } \\
\text { at } 25^{\circ} \mathrm{C} \text { and } 1 \mathrm{~m} / \mathrm{s} \text { airflow [12] }\end{array}$ \\
\hline
\end{tabular}

However, the operating temperature range of such sensors is broad (often from $-40{ }^{\circ} \mathrm{C}$ to $+125^{\circ} \mathrm{C}$ ) and the temperature affects the dynamic properties of a sensor as well as the steady ones. Information about the influence of temperature on the dynamic behaviour of that type of humidity sensor is available in the literature (e. g. [13]) but such publications are sparse, despite of the fact that capacitive humidity sensors dominate long on the market [1]. The numerical studies of this problem provide only limited progress in its understanding [14]. 
In this paper the results of the research performed on the dynamic behaviour of the capacitive humidity sensors for various step changes in the humidity level of moist air, within the temperature range from $-30{ }^{\circ} \mathrm{C}$ to $+20^{\circ} \mathrm{C}$ and under atmospheric pressure are presented.

In the following sections, the word "humidity" is used in the meaning "relative humidity", unless not stated explicitly otherwise.

\section{Experimental Setup}

In order to establish the dynamic behaviour of the polymer-based capacitive humidity sensors, the experimental setup depicted in Figure 1 was used. All the component devices of the setup were connected with the fittings and pipes of inner diameter of $4 \mathrm{~mm}$ (Swagelok), electropolished inside. The source of dry synthetic air (trace absolute humidity of $2 \mathrm{ppm}$, or ca. $-72{ }^{\circ} \mathrm{C}$ the frost point) was the steel bottle (not shown in Figure 1).

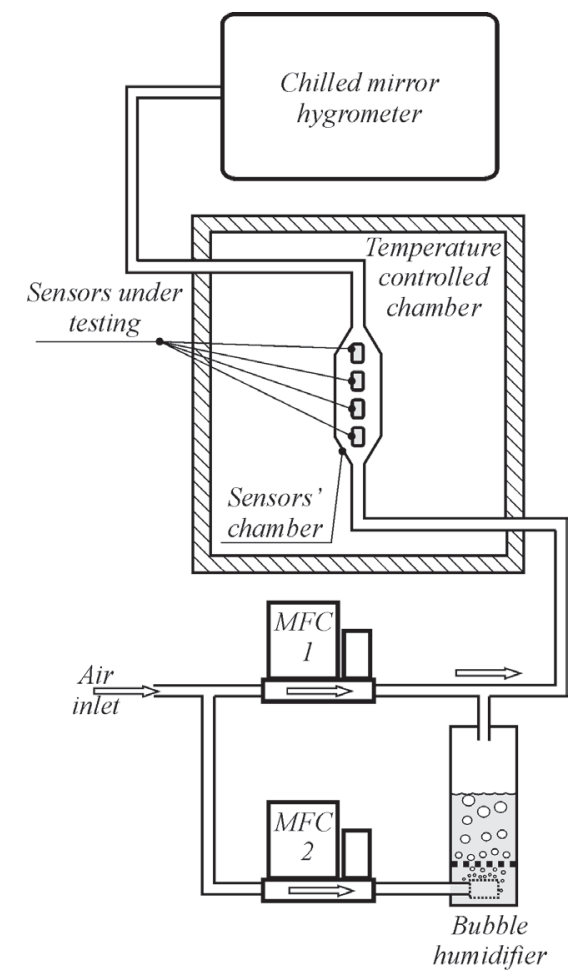

Figure 1 - The schematic view of the experimental setup (MFCs denote Mass Flow Controllers)

The air flow was split into two streams: the first stream was kept dry and passed through the mass flow controller MFC 1 directly towards the measurement chamber, whereas the second stream after passing the MFC 2 was humidified in the bubble humidifier. Then these two streams were mixed and fed into the small measurement chamber, mounted vertically in the middle of a bigger temperature controlled chamber. Inside the small measurement chamber four capacitive humidity sensors were fixed (together with a Pt 100 temperature sensor, not shown in Figure 1). The absolute humidity of the air stream at the chamber outlet was measured with a precise chilled mirror hygrometer. The inlet and outlet of the small chamber were cone-shaped in order to ensure a laminar flow; the flow rate of the air was kept at 1 $1 / \mathrm{min}$. The step change in the humidity level of the air flow was performed by the change in the flow of the air stream bubbled through the liquid water in the humidifier, introduced by the change in the settings of the MFCs. Both high and low changes of the relative humidity (denoted as $\Delta \varphi$ ) were realized.

In order to get the measurement profiles of various humidity step responses, after each step change the signals from the sensors were collected at $10 \mathrm{~s}$ time intervals at temperatures from $-30{ }^{\circ} \mathrm{C}$ to $+20^{\circ} \mathrm{C}$ at $10 \mathrm{~K}$ intervals.

The sensors under test were two SHT71 and two SHT75 pieces from the Swiss company Sensirion (see Table) manufactured in the CMOS technology, with embedded signal-conditioning electronics. This type of sensor is often applied in scientific facilities and space-oriented research (e.g. $[13,15])$.

\section{Results and Discussion}

Using the experimental setup described above, several measurement profiles of the dynamic behaviour of sensors under test were obtained, both for positive and negative steps in the humidity level. At a given temperature, the temporal profiles of responses to either small or high changes in humidity level do not differ remarkably from each other; a proportional scale change in magnitude can only be observed (Figure 2).

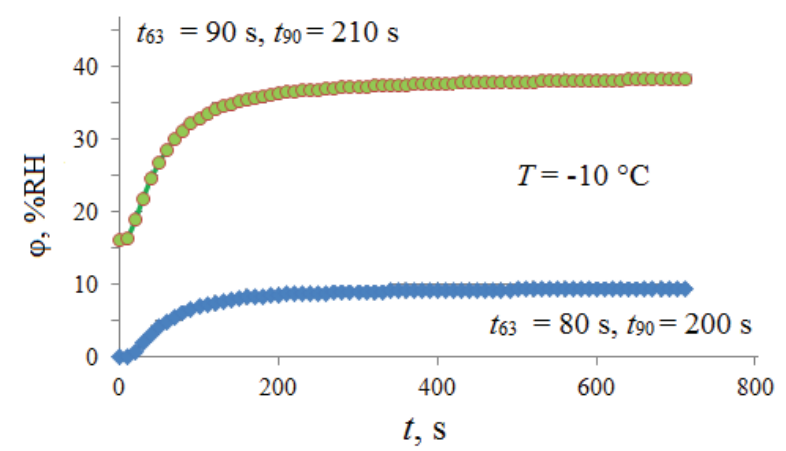

Figure 2-The comparison of two step response measurement profiles (for the small step - the profile in blue, for the big step - the profile in green) at $T=-10^{\circ} \mathrm{C}$ 
For each profile, the response time $t_{90}$ (or the recovery time $t_{10}$, respectively) was determined graphically; the exemplary profiles are shown in Figures 3 and 4.
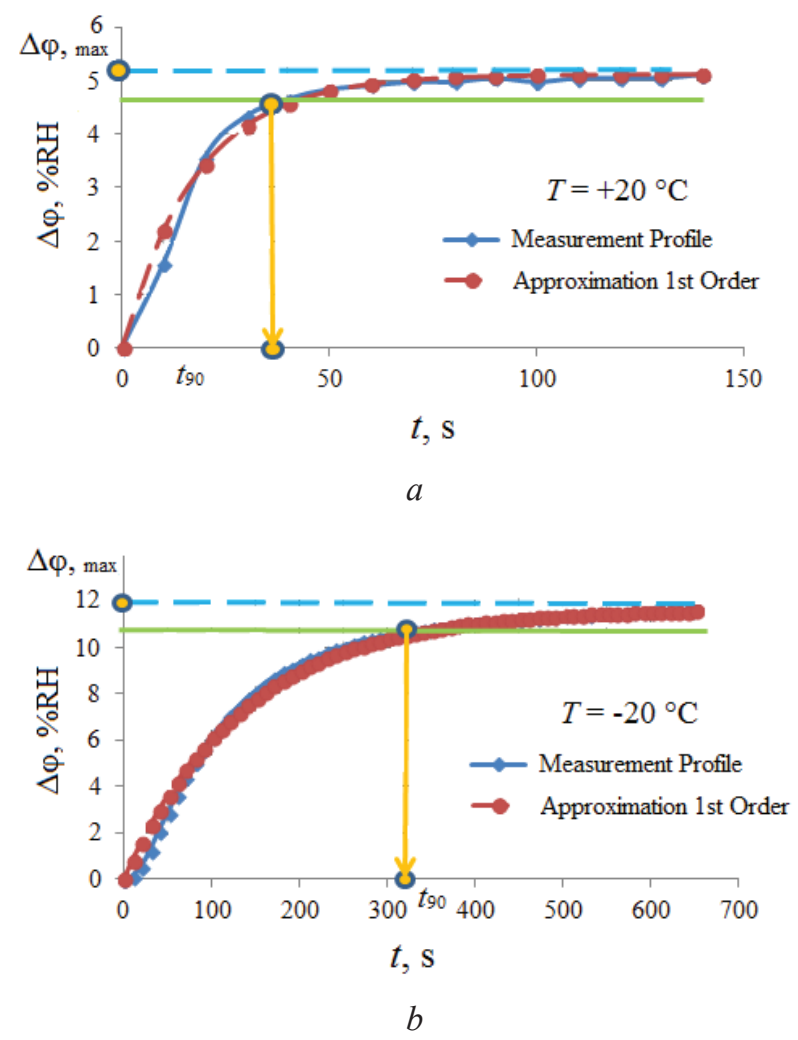

Figure 3 - The exemplary measurement profiles for the positive step change in humidity (solid lines) and their exponential approximations (dashed lines); the response time value $t_{90}$ is determined graphically: $a$ - response time $t_{90}=38 \mathrm{~s}$ at $T=+20^{\circ} \mathrm{C} ; b-$ response time $t_{90}=320 \mathrm{~s}$ at $T=-20{ }^{\circ} \mathrm{C}$

Also, each profile was approximated with an exponential fit of the sensor's step response, according to the first order differential model (shortly named on the plots' legend as "Approximation 1st Order"). For a positive step height $\Delta \varphi_{\max }$, the fitting function $\Delta \varphi(t)$ over time is expressed:

$\Delta \varphi(t)=\Delta \varphi_{\max } \cdot\left(1-e^{-\frac{t}{t_{63}}}\right)$

Analogically, for a negative step, the formula is written as:

$$
\Delta \varphi(t)=\Delta \varphi_{\max } \cdot e^{-\frac{t}{t_{37}}},
$$

where $t_{37}$ is the time constant (for a negative step), i. e. the time elapsed from the step change $(t=0)$ to the time instant when ca. $37 \%$ (or 1/e) of the step height $\Delta \varphi_{\max }$ is attained.
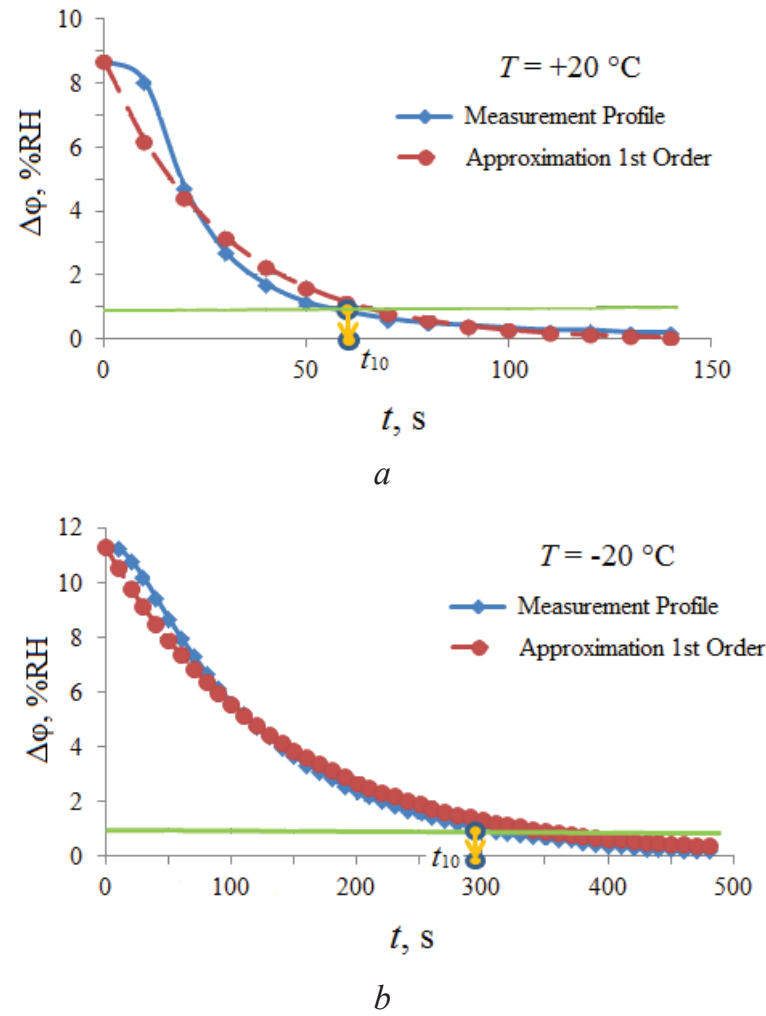

Figure 4-The exemplary measurement profiles for the negative step change in humidity (solid lines) and their exponential approximations (dashed lines); the recovery time value $t_{10}$ is determined graphically: $a$ - recovery time $t_{10}=60 \mathrm{~s}$ at $T=+20^{\circ} \mathrm{C} ; b-$ recovery time $t_{10}=295 \mathrm{~s}$ at $T=-20^{\circ} \mathrm{C}$

For almost all registered profiles, at the beginning near $t=0$ a small "foot" is observed, which depicts the deviation from the ideal exponential behaviour due to the mixing process in the small chamber (stirredtank flow) and in the tube leading the humidified air to the measurement chamber (piston flow).

However, for almost all temporal measurement profiles, the ratio $t_{90} / t_{63}$ (or $t_{10} / t_{37}$, respectively) is within the range $2.1-2.5$, which is close to the theoretical value of $\ln 10 \approx 2.3$ - the values of $t_{90}$ and $t_{10}$ (as well as $t_{63}$ and $t_{37}$, respectively) are similar for a given temperature. It also turned out that the dynamic behaviour of the polymer-based capacitive humidity sensors is strongly dependent on temperature, as depicted in Figures 5 and 6 ( $T$ denotes temperature).

Although the power function approximation of the dependencies shown in Figures 5 and 6 is possible, it seems that below $T=-20^{\circ} \mathrm{C}$ a different physical phenomenon dominates the process of equilibration than above $T=-20^{\circ} \mathrm{C}$, which makes the sensors' dynamic behaviour much slower. In the literature [13] are clues that below $T=-30{ }^{\circ} \mathrm{C}$ the response times $t_{90}$ are even much more slower 
(from about one hour at $T=-40{ }^{\circ} \mathrm{C}$ to several days at $T=-70{ }^{\circ} \mathrm{C}$ ).
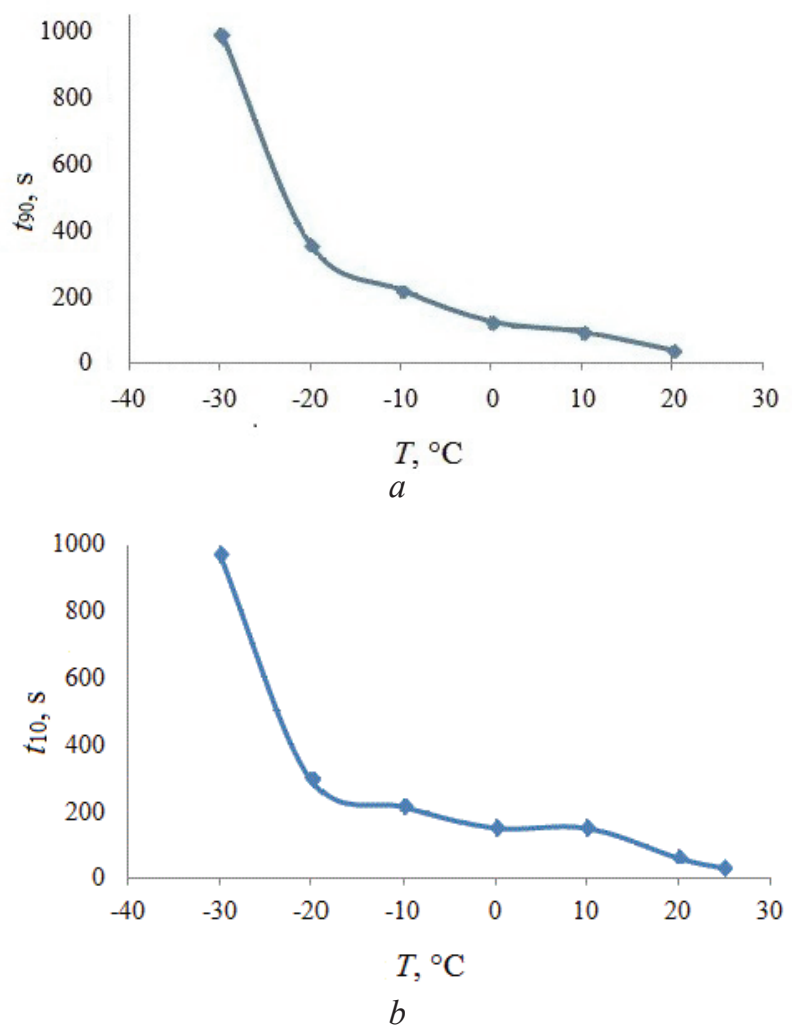

Figure 5 - The temperature dependence of: $a$ - response time $t_{90} ; b$ - recovery time $t_{10}$

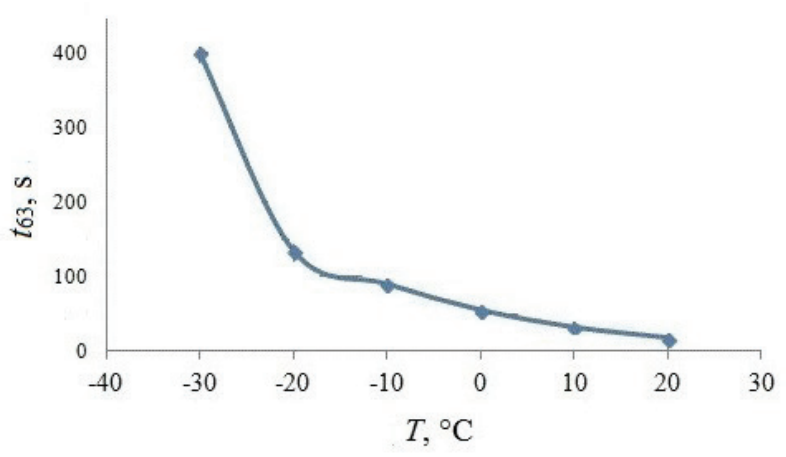

$a$

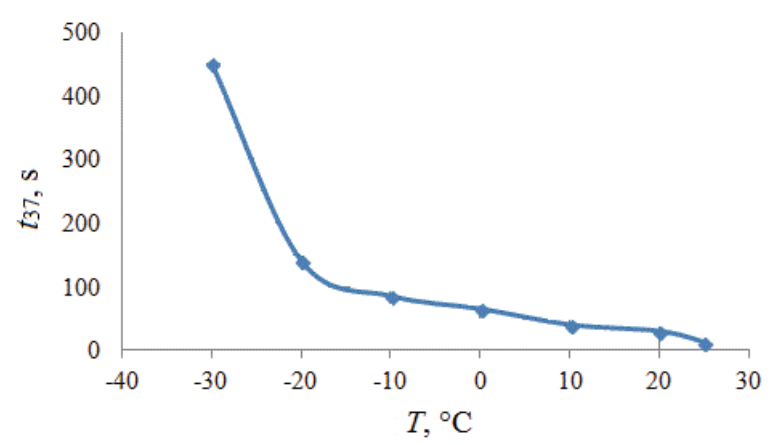

$b$

Figure 6 - The temperature dependence of: $a$ - time constant for positive step $t_{63} ; b$ - time constant for negative step $t_{37}$
The value specified in the $S H T 71$ and $S H T 75$ sensors' datasheet: $t_{63}=8 \mathrm{~s}$ (typically, at $T=+25^{\circ} \mathrm{C}$ and $1 \mathrm{~m} / \mathrm{s}$ airflow) is lower than the values obtained in this research, where the airflow applied was ca. $0.04 \mathrm{~m} / \mathrm{s}$; consequently, the new humidity equilibrium state was delayed in respect to the specified value.

\section{Conclusion}

After conducting the research and the literature quest, the following conclusions can be drawn. Firstly, the manufacturers commonly use the term "Response time" specified as e.g. $t_{63}$, which is usually labelled "Time constant", and is as a rule ca. 2.3 times shorter than $t_{90}$ (generally called "Response time" in the gas sensors' field); that may cause misunderstandings. In the specifications, the temperature dependence of $t_{63}$ is mostly omitted; other environmental conditions for which the specified value of $t_{63}$ is valid are provided only rarely.

Secondly, the dynamic behaviour of the polymer-based capacitive humidity sensors is slowed down when the temperature falls. This effect becomes more apparent at temperatures below $-20^{\circ} \mathrm{C}$ as the relationship between temperature and $t_{90}$ (as well as $t_{63}, t_{10}$, and $t_{37}$ ) becomes more nonlinear. It seems that below $-20{ }^{\circ} \mathrm{C}$ a change of the dominating physical phenomenon that governs the process of approaching the humidity equilibrium, occurs. This could be explained by the slower rate of surface adsorption (or desorption) of water molecules onto the polymeric film, as well as the slower diffusion rate (both adsorption and diffusion are temperature-dependent processes), especially at sub-zero temperatures.

Thirdly, at a given temperature value the step height changes the values of the sensors' dynamic parameters only slightly, for both the positive and negative step change. Also, the response and recovery times do not differ much, especially when the temperature falls below $0{ }^{\circ} \mathrm{C}$.

Finally, the temperature effect on the dynamic behaviour of the polymeric capacitive humidity sensors can influence the dynamic behaviour of an automation system containing such sensors when considerable changes in temperature occur (e.g. outdoors or in winter). The change in the surrounding conditions of the sensor environment other than temperature (e.g. the airflow) can also make the response times longer than the specified values. 


\section{Acknowledgement}

The author is indebted to the team of the Working Group 8.1 at the Bundesanstalt für Materialforschung und -prüfung (BAM), Berlin, Germany, for practical support and scientific discussion.

\section{References}

1. Lee Ch.-V., Lee G.-B. Humidity Sensors: $A R e$ view, Sensor Letters, 2005, vol. 3, pp. 1-14.

DOI: $10.1166 / \mathrm{s} 1.2005 .001$

2. Boudaden J., $\quad$ Steinmaß1 M., $\quad$ Endres H.-E., Drost A., Eisele I., Kutter C., Müller-Buschbaum P. Polyimide-Based Capacitive Humidity Sensor. Sensors, 2018, vol. 18, pp. 1506-1521. DOI: 10.3390/s18051516

3. Hübert T., Tiebe C., Detjens M., Majewski Ja. On-site calibration system for trace humidity sensors. Measurement, 2016, vol. 91, pp. 251-257.

DOI: $10.1016 /$ j.measurement.2016.05.013

4. Wildmann M., Kaufmann F., Bange J. An inverse modelling approach for frequency response correction of capacitive humidity sensors in ABL research with small remotely piloted aircraft (RPA). Atmospheric Measurement Techniques, 2014, iss. 7, pp. 3059-3069.

DOI: 10.5194 /amt-7-3059-2014

5. Detjens M., Hübert T., Tiebe C., Banach U. Coulometric trace humidity measurement in technical gases. Review of Scientific Measurements, 2018, vol. 89, 085004, pp. 1-8. DOI: 10.1063/1.5008463

6. Sensirion, the Sensor Company: Sensor Specification Statement, Version 1.1 - June 2018. URL: https://www. sensirion.com/fileadmin/user_upload/customers/sensirion/ Dokumente/2_Humidity_Sensors/Sensirion_Humidity_ Sensors_Specification_Statement.pdf.

7. Sensirion, the Sensor Company: Testing Guide, Version 1.3 - December 2018. URL: https://www. sensirion.com/fileadmin/user_upload/customers/
sensirion/Dokumente/2_Humidity_Sensors/Sensirion_ Humidity_Sensors_Testing_Guide.pdf.

8. Innovative Sensor Technology IST AG: K5-W Capacitive Humidity Sensor, DHK5-W_E2.2.1, Datasheet. URL: https://www.ist-ag.com/sites/default/ files/DHK5-W_E.pdf

9. HIH-4602-L Series Humidity Sensors, Honeywell, Datasheet, December 2008. URL: https://sensing. honeywell.com/honeywell-sensing-hih46021-seriesproduct-sheet-009043-1-en.pdf

10. HCT01 Humidity/Temperature Sensor, E+E ELEKTRONIK, Datasheet, Version 2019-05. URL: http://downloads.epluse.com/fileadmin/data/product/ hct01/datasheet_HCT01.pdf

11. Humidity Sensor HygroMer IN-1, Rotronic AG, Datasheet, 59013-E/2015-02. URL: https://www.rotronic. com/en/productattachments/index/download?id=997

12. Datasheet SHT7x (SHT71,SHT75) Humidity and Temperature Sensor, Sensirion AG, Version 5 December 2011. URL: https://www.sensirion.com/fileadmin/user upload/customers/sensirion/Dokumente/0_Datasheets/ Humidity/Sensirion_Humidity_Sensors_SHT7x_ Datasheet.pdf

13. Lorek A. Humidity measurement with capacitive humidity sensors between $-70{ }^{\circ} \mathrm{C}$ and $25^{\circ} \mathrm{C}$ in low vacuum. Journal of Sensors and Sensor Systems, 2014, vol. 3, pp. 177-185.

DOI: $10.5194 /$ jsss-3-177-2014

14. Zhou W.-H., Wang L.-Ch., Wang L.-B. Numerical Study of Structural Parameter Effects on the Dynamic Characteristics of a Polyimide Film MicroCapacitive Humidity Sensors. IEEE Sensors Journal, 2016, vol. 16, no. 15, August 1, pp. 5979-5986.

DOI: $10.1109 /$ JSEN.2016.2579644

15. Lorek A., Majewski J. Humidity Measurement in Carbon Dioxide with Capacitive Humidity Sensors at Low Temperature and Pressure. Sensors, 2018, vol. 18, pp. 2615-2626. DOI: $10.3390 / \mathrm{s} 18082615$ 